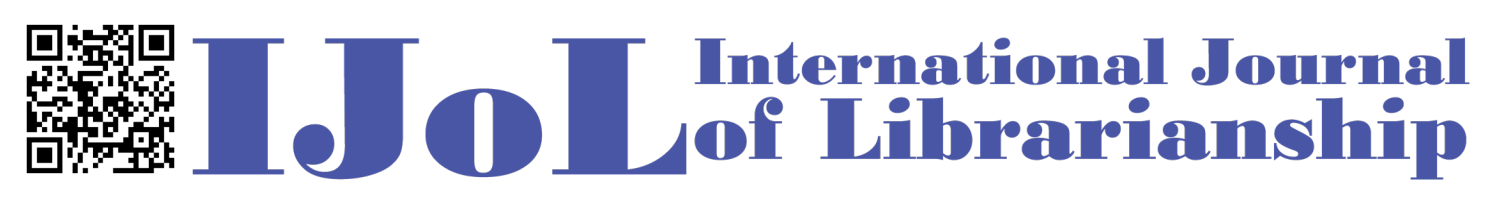

ISSN: 2474-3542 Journal homepage: http://journal.calaijol.org

\title{
Evolution of Western Library Catalogs: The Rising Expectations of Users
}

Junli Diao

\begin{abstract}
:
This paper traces the historical development of library catalogs from primitive catalogs in ancient times to current next generational catalogs, which are summarized into three stages: the agricultural catalog stage, the industrial catalog stage and the information catalog stage. In particular, this paper focuses on the discussion of the rise of users' expectations on library catalogs at different stages and gives emphasis to what impact they have created accordingly.
\end{abstract}

To cite this article:

Diao, J. (2018). Evolution of Western Library Catalogs: The Rising Expectations of Users. International Journal of Librarianship, 3(1), 78-93. doi: https://doi.org/10.23974/ ijol.2018.vol3.1.69

To submit your article to this journal:

Go to http://ojs.calaijol.org/index.php/ijol/about/submissions 


\title{
Evolution of Western Library Catalogs: The Rising Expectations of Users
}

Junli, Diao

York College, City University of New York

\begin{abstract}
This paper traces the historical development of library catalogs from primitive catalogs in ancient times to current next generational catalogs, which are summarized into three stages: the agricultural catalog stage, the industrial catalog stage and the information catalog stage. In particular, this paper focuses on the discussion of the rise of users' expectations on library catalogs at different stages and gives emphasis to what impact they have created accordingly.

Keywords: library catalog, cataloging, evolution, user, users' expectation, primitive catalog, alphabetical list, codex, printed book catalog, card catalog, online catalog, next generational catalog, NGC
\end{abstract}

\section{INTRODUCTION}

Library catalogs are frequently used, but how they evolved into what they are has not been fully addressed in the library and information science literature. Norris (1939) surveyed the history of catalogs and cataloging methods, with an intensive discussion of a temporal span starting with the Middle Ages and ending in the middle of 19th century. Clarke (2014) delivered a historical review of library catalogs from ancient times to the present and concentrated on the argument of the alternative functional purposes that library catalogs pertain to serve beyond finding, selecting, identifying and obtaining library materials. Most of cataloging textbooks focus on the methodological and practical explanation and analysis of systematically describing, representing, organizing and classifying resources, chiefly touching the progress of modern library catalogs after 1800. Fons (2016) reviewed the evolution of library catalogs and librarianship and emphasized the convenience and efficiency that catalogs bring to users. Therefore, this article attempts to add to the discussion about the historical trajectory of the development of library catalogs from ancient 
times to the current period, with particular exploration of the role that user expectations played in the development, which has never been examined.

In order to trace the evolution of library catalogs, one must first discuss and clarify the definition of catalogs. Joundrey, Taylor, and Miller (2015) considered that "a catalog is an organized compilation of bibliographic metadata that represents the holdings of a particular institution and/or resources accessible in a particular location" (p. 7). Chan and Salaba (2015) indicated that a library catalog is a bibliographic file which provides the items in the collection or collections the catalog represents with data that describes the physical characteristics of the resource and offers the physical item with identification numbers, subject content and physical location of the item in the collection (pp. 23-24). Definitions of such in cataloging textbooks are elaborated and extracted from the characteristics and principles of contemporary library catalogs. The major trait of library catalogs, described as an aggregation of structuralized bibliographic metadata, did not exist in the pre-modern period. A contemporary-based and affirmative definition could either say too much or too little. If one follows the contemporary impression of what a library catalog is, one runs the risk of forgetting our remote past and failing ourselves for being shortsighted about our exciting future. Therefore, defining library catalogs, which is an historic term, is not an easy task. While celebrating the monumental achievement of the card catalog, the Library of Congress in its book The Card Catalog: Books, Cards, and Literary Treasures articulated that the card catalog was "a road map for navigating the wilderness of books" (p. 9). If this definition could be expanded beyond books and the card catalog environment, one would say that a library catalog was a road map for navigating the wilderness of library resources, or a library catalog serves as a gateway that bridges library users' needs and library resources. A broad, open and inclusive definition like this might be a safer and wiser idea for one to approach an historic term, which will help us embrace the conceptual mode what a catalog is and what purpose it serves, regardless of material formats, supporting techniques and organizing principles, and which will help us understand that our current library catalogs have come a long way.

\section{PRIMITIVE CATALOGS IN ANCIENT LIBRARIES}

Archaeologists have contested that some of the earliest libraries, dating from approximately $3,000 \mathrm{BCE}$ to 2,300BCE, are located among the ruins of the most ancient cities of the Tigris Euphrates valleys (Tolzmann, Hessel, \& Peiss, 2001). The excavated clay tablets with cuneiform scripts provide us with a glimpse of earliest library collection management: grouping objects by their physical attributes or listing by types of the content.

In the ancient city of Ebla in Syria, the room close to an audience hall holds tablets that documented the business of state and the smaller rooms contain tablets concerning economic affairs; round tablets stored on the floor specially contain economic and administrative texts, and 
square ones don't have such preference but are stored on the middle and upper shelves; moreover, clay tablets contained lists of kings, gods, cities, states, objects, animals and professions (Wellisch, 1981, pp. 490-496). A more sophisticated list of titles taken from the first line of texts or a brief summary of the contents of clay tablets was found in the ancient city of Hattusas in Turkey (Casson, 2001, p. 6). It contains titles of literary works used as a "point" to represent a whole literature work. As we know, listing is metacognitive behavior that involves calculating, sequencing and abstracting information, which makes itself one of the fundamental activities giving birth to library catalogs. If one recalls the common definition that metadata is data about data, one would get an inspiration that choosing a title to represent an entire literary work in the city of Hattusas's library could be regarded as primitive metadata creation activity. Such a list then would be a proven "primitive catalog."

Since literacy is closely tied to power in ancient times, users of ancient libraries should be a small number of the ruling classes, such as kings, royal families, government officials or other significant figures. Scribes who mastered and interpreted the complicated and sacred writing system can be considered as librarians (Tolzmann, Hessel, \& Peiss, p. 4). It was believed that the capability of reading messages from the text graced them with the power and privilege of communicating between earthly beings and heavenly spirits (Lyons, 2011, p. 17). Perhaps library users in ancient times were immensely awed by the primitive catalogs, which not only offered them certain convenient access to obtain what they wanted among the countless clay tablets, but also a theological pathway leading to the acquaintance with earthly beings and heavenly spirits.

\section{ALPHABETIC LISTS IN GREEK AND ROMAN TIME}

Libraries in ancient times functioned more as "storage" halls. As growing social complexity and productivity gave rise to new approaches of communication, libraries gradually developed into houses of knowledge and the collected texts demonstrated a high level of narrative skill and intellectual output (Casson, 2001, p. 17). Alphabetic sequencing began to be employed in the library's collection management.

In ancient Greece, an increasing number of libraries emerged and blossomed, including government sponsored libraries, so-called public libraries that only opened to a small population who were able to read, and private libraries owned by prominent scholars (Murray, 2009, p. 14). The famous Alexandrian Library (300BCE-48BCE approximately) had a collection of around 490,000 papyrus rolls on the scholarship of language and literature in the main hall, which were shelved by alphabetical order from the beginning (Casson, 2001, p. 36). Later, one of the most important scholar librarians, Zenodotus, employed alphabetical sequencing in the compilation of a glossary of rare words. Another famous scholar librarian, Callimachus, compiled annotated bibliographies called "Pinakes," which classified works by subject and arranged them alphabetically by authors with biographical information and listing of works supplied (Tolzmann, Hessel, \& Peiss, 2001, p. 8). Such an arrangement and description of collections gained its canonical reputation and brought profound impact to bibliographic practices in the history of 
library science. After Greece fell, Rome rose and inherited its culture and legacies. In Roman times, libraries flourished but very few libraries employed bibliographical catalogs that were arranged by authors' names, under which titles or first lines of the work, lengths of works, and occasionally biographical information were supplied (Johnson \& Harris, 1976, p. 70).

Hypothetically speaking, Greco-Roman society was a "literate" one. The Greco-Roman culture and civilization were disseminated and rooted through libraries in places where the empire reached. Library shelves were filled with epics of Homer, works by great philosophers, literature, laws, and works by professionals. Librarians or library administrators were scholars, like Zenodotus and Callimachus in ancient Greece or very well-educated slaves in the Roman Empire. Users of libraries were learned and liberated persons who were passionate about books and libraries. Author-alphabetical catalogs created by librarians or library administrators were not merely a label of identification, but also the groundwork unconsciously laid for the principle of authorship in the future world. Library catalogs have demonstrated a sense of conceptualization and abstracting while describing and organizing textual materials. Users, who either inhabited cities or made their way to libraries from afar, would be captivated by such intelligent endeavor and gave their salutation and admiration to librarians who organized collections in such a manner.

\section{MANUSCRIPT CODEX CATALOGS}

If papyrus rolls are a sign of ancient libraries, then the parchment codex libraries are characteristic of the Middle Ages (Tolzmann, Hessel, \& Peiss, 2001, p. 17). Papyrus rolls were subject to changes of climate and they deteriorated easily in wet and damp areas. By the fifth century, papyrus rolls had been replaced by a new material - parchment, chiefly made from the skins of sheep and goats, and began to earn their place on the shelves of libraries (Murray, 2009, p. 14). Library catalogs took a new physical form - the manuscript codex.

The fall of the Roman Empire buried libraries with classical texts. The rise of Christianity brought forth ecclesiastical libraries with theological manuscripts. In the early Middle Ages, libraries were chiefly monopolized by churches. In the Late Middle Ages, university and college libraries began to emerge. Strongly influenced by church libraries, college and university library collections were dominated by religious works, in addition to a small number of subject collections on philosophy, mathematics, medicine, astronomy and some local materials (Johnson \& Harris, 1976, p. 122).

In general, libraries in the Middle Ages were relatively small and collection management mainly depended upon librarians' knowledge and memorization. Some relatively big libraries had catalogs, taking the form of pure inventories or accession lists of books organized by authors, titles, or a catchword from the title or the first line of the text (Harris, 1984, p. 92). Alphabetical ordering, an important technique developed and used in Greek and Roman times for arranging collections, glossaries and lexica, was not fully utilized by libraries in Medieval Times. In some academic libraries, the catalogs or booklists were arranged more or less alphabetically, but sometimes indiscriminately by author, title, catchword, or size (Johnson \& Harris, 1976, p. 122). However, 
this doesn't necessarily mean that the evolution of catalogs during the Middle Ages remained at a standstill. Although Europe's political landscapes were divided by feudal kings, nobles, and manors with the support of a self-sufficient economic system, what penetrated the boundaries and divisions of kingdoms and states was the church, exerting a powerful influence on all aspects of life and unifying and stabilizing Europe under one big umbrella-Christianity. Possibly inspired by Christian uniformity, some monks created a union catalog that covered the major books collected in monastic libraries, one of which in England was an alphabetical catalog with the indication of locations by numbers (Harris, 1984, p. 92).

Compared with the "literate" Greco-Roman period, literacy in the Middle Ages was declining. Low literacy and theological control enshrined the well-educated librarians, who were in charge of books and reading. Church libraries mostly served monastic scholars inhabiting the designated local monasteries or visiting monk scholars from other churches. Non-ecclesiastic users of medieval libraries usually were the privileged classes, including nobles, government officials, or monastery benefactors, and also rising merchants as commerce rose and expanded in Europe (Murray, 2009, p. 33). With the rise of colleges and universities during the late Middle Ages, an increasing number of students and scholars came to be educated with religious work and classical learning, creating significant impact on library planning and facilities (Murray, p. 66-67). However, given the size of collections, users' influence in library catalogs, either in church libraries or academic libraries, seemed to be extremely insignificant during this period, even though the privileged classes might exert political, cultural and even personal influence on library collections through their patronage.

\section{Printed Book Catalogs}

Innovation, individualism, democracy and civil liberties gradually sprouted after medieval Europe and transformed the European political, social and cultural landscape. The technique of papermanufacturing and the advance in movable type printing gave birth to printed books, which disseminated information on a massive scale and perfectly matched with the enlightened civilians' and intellectuals' emerging demand for reading and learning. The foundation of European monarchies and the Catholic Church were shaken by the Enlightenment and the French Revolution. Monastery libraries were secularized and royal libraries were nationalized as state properties. The center of the house of knowledge was shifted from church libraries to academic and national libraries. The increased size of library collections and capacities called for a corresponding catalog - the printed book catalog, which had the ability to be used by multiple users simultaneously.

The Bodleian Library of Oxford University in England had its first printed catalog in 1605 and the second in 1620. The first catalog contained entries for 4,000 manuscripts and printed books utilizing techniques like interfiling, alphabetical listing and subject classification; the second one was improved by the introduction of cross-references, publication information, and book location in the library (Ranz, 1964, pp. 2-3). The British Museum Library tried to create a printed book catalog but the attempt was delayed for more than half a century by the inability to decide between a strictly-alphabetized catalog, which enabled users to find a particular known item, or a subject 
classed catalog, which permitted users to find one and its related items by taking a reasonable guess of the right subject. It was not until 1900 that a 47-volume printed book catalog eventually came out, including a ten-volume supplement that added books acquired from 1882 and 1889 (Norris, 1939, p. 213). In colonial America, the Library of Harvard College created its first printed book catalog in 1723, which was "arranged first by size and then alphabetically through the first letter of the entry word" (Ranz, 1964, p. 9). Unlike the British Museum Library's struggle between an alphabetical catalog and a classed catalog, American libraries took great courage and effort to enthusiastically experiment with both approaches. American librarians' endeavor and creativity brought the United States to the center of the international arena of library development.

The Renaissance, the Reformation, and the Industrial Revolution brought about a radical transformation to European intellectual life. Users of libraries were modern European men and women who cast aside the yoke of Medieval Times. Their thriving for scholarship and professional advancement accelerated the size and complexity of library's collections. In colonial America, the tradition of education and self-employment of the pioneers and their descendants in fast-growing settlements created a hunger for books in both humanities (art of thinking) and sciences (art of doing) (Murray, 2009, p. 153). The expansion of collections and the influx of users pressured librarians to formulate a practical strategy to classify and manage books systematically and efficiently. After the failed attempt to arrange books by size and their acquisition dates, a titlealphabetic or a subject-classed printed book catalog dominated libraries in the 18th and 19th centuries in Europe and America. The positive effect of printed book catalogs was apparent. They were in print format and could be reproduced in multiple copies as desired. Users could hold one volume in their hands and spend as much time as they needed to browse without interfering with others or keeping them waiting behind. Users were very much attracted by the appealing visual representation of book catalogs. The uniformity of book description and the systematization of the arrangement of titles and analysis of subjects within the catalogs could stimulate users' thinking and learning. Moreover, the printed multivolume catalogs gave librarians themselves a strong sense of satisfaction and accomplishment after the intelligent project was wrapped up, because they embodied the library tradition in the book format that librarians had been accustomed to seeing for a few centuries (Ranz, 1964, p. 41). However, compiling book catalogs was labor intensive and printing them was costly. They became out-of-date immediately after the printing was finished. There was no way to insert the incoming collection into the printed catalogs, which usually frustrated users and failed their expectations. To overcome this disadvantage, libraries were forced to print supplements as a remedy or print bulletins of new acquisitions periodically or try other innovative ways to make new acquisitions visible (Ranz, p. 46).

\section{PRINTED CARD CATALOG}

The combination of steam, iron and electricity speeded up the wheels of machines, which dramatically increased the quantity and variety of industrial products from 19th century onwards. Mass production supported by divisions of labor and specialized techniques not only generated a 
demand for skilled professionals and educated civil citizens, but also led to the standardization of tools and products so as to attain unified, interoperable and efficient services. Inescapably impacted by this social trend, library catalogs were transformed into a dazzling new chapter- the standardized card catalog.

The origin of the printed card catalog was conceived in the paper slips used to present bibliographical information in the 16th century in Germany and playing cards adopted to organize and describe books transferred from ecclesiastic and royal libraries during the French Revolution (Valentine, 2012, p. 149). In 1861 the Harvard College Library made its card catalog open to the public and its flexibility brought huge convenience to both librarians and users (Ranz, 1964, p. 53). In addition to flexibility, the groundbreaking and revolutionized aspect of the card catalogs lies in the potential that designing, manufacturing, printing, filing and storing cards could be standardized, as well as bearing information. With a great vision beyond the era, Melvil Dewey (1851-1931), the designer and creator of the Dewey Decimal Classification, made a strong effort to bring standardization in various aspects of library operations and feverishly persuaded the Library of Congress (LC) to undertake a leadership role in providing centralized cataloging services and creating and distributing standardized cataloging cards to American libraries. Not until 1901, though, did the LC officially proclaim this responsibility to print and distribute the standardized $3 \times 5$ inch cataloging cards to libraries across the whole country, which carried the LC's extraordinary achievement in library science: LC Classification and LC Subject Headings. Under the principal of standardization, every book went through the same standardized cataloging procedure by experts and every catalog card carried an equal amount of information in terms of quantity and quality. Therefore, libraries, no matter the "smaller libraries in the farthest corners of the country" or "the greatest ones in the world," were put in equal status by providing users with the same quality catalogs (The Library of Congress, 2017, p. 113).

Capitalism and industrialization increased the population who had faith in self-empowerment and sought self-improvement through education and learning. To acquire knowledge and wisdom or improve their lives and careers, they flowed into libraries and became persistent users for educational, professional and recreational reading. A standardized catalog allowed users to either promptly find the desired book or simply predict where similar books might be shelved. Users' eagerness and insatiability for books gave impetus to libraries to design an unprecedentedly sophisticated catalog that could clearly and precisely show users where individual books were located on the bookshelves, as well as the neighboring books of the same or similar subject. The emergence of card catalogs definitely met this need with clarity, precision and systematization of information achieved through structured numerical numbers, signs or alphabets. Such a catalog, integrated with alphabetized entries, formatted bibliographical descriptions, crossed references, coordinated subject headings and structured call numbers, grew out of librarians' sole crafting endeavor and turned out to be both a library's home-made hallmark of that era and a monumental cornerstone in the history of libraries. Such a catalog not only presented metadata information desired by users, but also carried a built-in collective identity and legacy of the library community as a whole, as opposed to the pre-card-catalog time when library catalogs were tied to individual librarian's credit and endeavor. Card catalogs became a prominent marker of library community 
which defined what librarians had achieved together. Such a catalog was not a commercial product developed by vendors and sold back to libraries. Librarians were the designers and creators.

\section{ONLINE CATALOGS}

Electronic computer and internet technology revolutionized the view of how data was stored, manipulated and transferred. When they were introduced into library settings, the nature of a library's catalog was profoundly changed. In 1966, Henriette D. Avrams launched the first automated cataloging system well-known as Machine-Readable Cataloging (MARC). It did not take very long for its value to be recognized and accepted by the international library community as an efficient and effective replacement of the cumbersome and labor-intensive card catalogs. Ohio State University and Dallas Public Library integrated MARC records in their library systems and implemented large-scale online catalogs in 1975 and 1978 respectively (Borgman, 1996, p. 499). Soon after, the library community followed their actions and started converting card catalogs into machine readable online catalogs and gaining bibliographic automation in managing library collections.

Strongly influenced by its predecessor, the first generation online catalogs provided an emulation of card catalog search experience characterized as finding known items (typically author, title and control numbers), which lacked authority control and cross-reference (Hildreth, 1987, p. 650). The second generation online catalogs "represent a marriage of the library catalog and conventional online information retrieval (IR) system familiar to librarians who search online abstracting databases via DIALOG, BRS, ORBIT, MEDLINE, etc." (Hildreth, 650-651). Added features included subject access, Boolean operators, truncation, etc. In the $1980 \mathrm{~s}$, an increasing number of commercial vendors began to provide libraries with more comprehensive and reliable integrated and multifunctional library systems, which covered the major functions of all types of libraries, including cataloging, acquisition, circulation, public access interface, and even library facilities' booking and usage (De Gennaro, 1983, p. 633). The public access catalog, commonly known as Online Public Access Catalog (OPAC), started to offer advanced features and services to users, such as applying limits to refine the search results by language, year, record type, format type, and location, as well as reserving titles or gaining remote access to library subscribed databases. With all these advantages, OPACs prevailed for decades and are still prominently used by libraries which haven't completely migrated to next generation catalogs.

Apparently, the emergence and development of online catalogs seemed to be propelled by technological innovation and financial considerations. Soon after online catalogs were introduced into libraries, card-catalog users were attracted or intimidated by the technologically refreshing and exciting interfaces that provided both searching and browsing functions. To be able to adapt to a completely new catalog and master the system effectively, users themselves needed to learn. Users needed to be trained and educated by public service librarians, or learn from reading printed handouts, or by participating in programs and workshops offered by the libraries. As online catalogs grew more sophisticated and complicated, libraries' instruction on helping users how to 
effectively retrieve and evaluate information became even more crucial, especially in the context of research and academic libraries. Online catalogs cannot be seen only as a bibliographic facility tools that show what libraries collect and subscribe. They are an instructional device that cultivates users to the realm of how information is guided by the conventions of scholarly community in organization, storage, production and retrieval (Peters, 135-136).

The notion that online catalogs turn out to be instructional devices doesn't necessarily mean that users are just information consumers, who quietly sit and attentively receive training or education offered by libraries in locating, retrieving and evaluating library resources, without inserting any influence on the catalog system or librarians' perceptions of their roles. As a matter of fact, users of online catalogs deliver a noticeable backwash impact both on the system and librarians' perceptions through their information seeking needs and behavior, which was originally ignored, or at least unforeseen by the system designers. Online catalogs in the 1970s and 1980s were technically directed by bibliographic networks, vendors and technical services librarians, not by the needs and expressed wishes of the library patrons (Adams, 1988, p. 33). To become competent online catalog users, they have to learn how to organize and synthesize ideas and translate them into queries, posing queries into databases and get the results that they wanted. In the 1990s, user interfaces of online catalogs were significantly improved, but the improvements stayed on the surface without reaching the core functionality concerning users' inner motivation and physical behaviors in the process of searching for information and dealing with information obtained (Borgman 1996, p. 501). However, what was ignored in libraries' online catalogs was captured by commercial websites. Users strongly influenced by Web searching, such as Google and Amazon, which both have clean boxes, criticize that libraries' online catalogs function like robots, neither intellectually intuitive nor stimulating, which create a necessity of providing further assistance to facilitate the search and help accomplish their tasks, such as handouts and training classes. Therefore, online catalogs as an instructional tool and online catalogs lacking the consideration of users' needs and information seeking behaviors could be considered as two sides of the same coin. Absence of the consideration of users' needs enhances and amplifies the necessity of libraries' instruction or training; through libraries' instruction or training, users bring to surface the hidden aspect that online catalogs lack a friendly design based on what they really want. This poses a question, "should libraries continue educating their users or should libraries adopt a new system that emphasizes users' needs?" Perhaps, next generation catalogs could answer this question.

\section{NEXT GENERATION CATALOGS}

At the beginning of the 21 st century, the breakthrough in computer technology, network, and new materials has greatly increased the abundance of information accessed, disseminated and reconstructed. Semantic Web and Linked Data technologies show great potential in giving Web content identity, structural relationship and semantic meaning; the application of Web 2.0 increases both global networking and interpersonal interactions and communications in a collaborative and 
end-user-friendly approach through personal, portable and intelligent devices. The sizes of devices are getting smaller but the capacities are bigger and the functions have multiplied, which makes seeking information online an entirely different experience. Changes in technologies lead to new tools and systems that upgrade or overturn their predecessors very quickly. Change becomes a new constant.

In the 1990s, tentative discussions began to emerge on what a future library online catalog should do. Rosenthal (1991) implied that the online catalogs should be able to work as a portal with the capacity of searching libraries' whole collections (p. 10). Turner and Cobbe (1990) indicated that online catalogs should be capable of interacting with other online systems (p. 52). Morgan brought up the definition of Next Generation Catalogs (NGC) for discussion via NGC4Lib mailing list and articulated four principles of NGC: "it is not a catalog, it avoids multiple databases, it is bent on providing services against search results and it is built using things open" (as cited in Nagy, 2011, p. 11). Although these tentative discussions sounded a little vague at the time, it did suggest that the library community attempted to decouple itself from the rigid online catalogs and explore the possibility of replacement that aims at having the entire collections covered in one single search and providing better services that could reflect users' needs. The first NGC was implemented in 2006, when the North Carolina State University Libraries launched the Endecapowered discovery layer over catalogs, offering a refreshing end-user search experience that demonstrated advanced features and enhanced functionalities. Since then, an increasing number of libraries, especially academic libraries, have gradually replaced their outdated and clumsy OPAC with the intuitive and easy-to-use NGC.

NGC, which came to be known as discovery tools, discovery layers, or web-scale discovery services, provides searches through "centralized index of metadata obtained from many publishers and database vendors as well as the subscribing library's OPAC, institutional repository, and other selected resources, returning results almost instantly" (Rose-Wiles \& Hofmann 2013, p. 150). In addition to the centralized index that empowers resources that libraries own and subscribe to, NGC offers end-users interfaces equipped with intelligent functionalities, such as one single point of entry to all library resources, simple search interface, faceted navigation, relevance ranking, rating, spelling suggestions, recommendations, user contributions, auto citation generation, social media integration and FRBR display, just to name a few (Dragomir, 2016, p. 18).

The typical NGC, such as WorldCat Local, Summon, Primo, Encore, AquaBrowser, and Endeca, is a third-party product provided to the library community by vendors that possesses cutting-edge technologies, able support and necessary resources. However, the emergence and implementation of NGC are not only propelled by a pure technology stimulus or business profits, but also driven by the change of demographic landscape - the rise of the Millennial generation, who were born between 1982 and 1998 and comprises the major population of current colleges and universities' enrollment (U.S. Census Bureau, 2017). Millennials are "Digital Natives" (Fromm \& Garton, 2013, p. 19). After they were born, they were blessed with technology advances. Computers, internet, digital cameras, digital music players, cell phones, and other digital devices became an extension of their bodies. Intimate interaction with digitals led Millennials to develop a mindset different from previous generations. They tend to be impatient, exploratory and results- 
oriented learners; they are digital natives, multitaskers, and gamers who love human-machine interaction; they are both information consumers and generators who seek choices and convenience in the way to approach the world, and they prefer personalization and customization in utilizing their products and services (Sweeney, 2006, pp. 2-10). Commercial websites, for instance, Amazon and Ebay, capture those characteristics precisely and correspondingly create new or update existing products and services, making them customized to Millennials' behaviors and needs. Users with such experiences walk into our libraries and they find that our OPAC is nothing but a dull and cumbersome tool to use. NGC, equipped with fast-responded, engaging, interactive, facet-navigated, and social-media-integrated search interface and functionalities, not only give Millennial users familiar searching experience gained from commercial websites, but also grant users more power and freedom to personalize, customize and socialize their search results. By doing so, Millennial users develop their digital identity in the library community and gain a strong sense of ownership and satisfaction.

\section{THE RISING EXPECTATIONS OF USERS}

From primitive clay tablets' lists to most recent NGC discovery tools, library catalogs progressed continuously and cumulatively for over thousands of years. On the time axis, the continuity and cumulativeness are conjectured into three broad evolutional stages by two distinctive fault lines, where technology brought about innovation and change. These three stages are the agricultural catalog stage, the industrial catalog stage and the information catalog stage. During the agricultural catalog stage, the form of catalogs was compilations of natural and raw materials with some handcrafting refinement. Library catalogs were a pure inventory of text-bearing but handcrafted objects, namely clay tablets, papyrus rolls and skin codices. Arranging such objects was more inclined to recordkeeping purpose. During the industrial catalog stage, the form of catalogs was profoundly transformed by the marriage of printing technology and paper-manufacturing. Every piece of the massively-produced books was inseparably interwoven with machinery elements. Industrial operations standardized procedures and products, textualized and typographicalized ideas and thoughts, and quickly made agricultural handcrafts obsolete. Library catalogs, whether printed book catalogs or card catalogs, could no longer be easily and accurately perceived by the naked human eyes what materials they were made of. After the digital binaries in computer and internet technology reshaped the form of catalogs in the way users get access to, utilize, disseminate and interact with texts, library catalogs were entering the beginning of the information stage. Online catalogs bring libraries beyond walls and libraries are tsunamied with information. Instead of dropping an anchor into the sea of information to maintain the stability of tradition and glory, the library community tests the waters and follows the tides and rejuvenates online catalogs into a dynamic discovery tool that offers a platform for both learning and socializing.

\section{The Agricultural Catalog Stage}

When library catalogs were growing slowly at the agricultural stage, library users had extremely 
limited impact or influence on the catalogs. The perceivable reasons are twofold. First, the number of users who could gain access to library materials was fairly small. In the agricultural stage, literacy was controlled by a small number of ruling classes, the capability of reading and writing was closely tied with bureaucratic, administrative, legal and religious systems. Even centuries after alphabetic writing was introduced, the restrictions on literacy remained to a few similar functions (Kaestle, 1985, p. 15). Secondly, compared with the illiterate mass, librarians were men of learning, men of the literate and men of knowledge. Valued by the ruling classes, librarians earned their status as literati by being the gatekeepers of libraries. One could argue a logical inference that librarians might be in a totally dominant position in terms of administering libraries and organizing their collections. Users could be in an inferior, humbled and passive position, accepting whatever approaches that librarians took to give order and direction to libraries' collections. Such a dichotomous relationship that one projects between librarians and users could be a reflection of the sociopolitical stratification in human society where restricted literacy and oral culture prevails. "Rather than fashion their world with clay or earth, librarian-gods breathe life into existence by providing structure" (Maxwell, 2006, p. 43). If Maxwell's remark is literally taken, it may perfectly match with library catalogs during the agricultural stage, when librarians designed the methods of arrangement without considering what users need.

\section{The Industrial Catalog Stage}

In the agricultural catalog stage, God was considered as the power. When library catalogs were taken into the industrial stage by printing presses and paper manufacturing, libraries gradually shifted their major roles from bookkeeping storages to book-reading centers and knowledge was considered as the spring of power. Compared with users during the agricultural stage, users in the industrial stage became significantly active and their increased patronage activities started to exert certain "pressure" onto librarians' work. Widespread literacy promoted the norm of typographical features and regularization of scholarly practices. New scientific ideas, new geographical discoveries and new ways of thinking demystified and secularized God's grace. Western scholarship and knowledge disciplines flourished. Books found their natural places-on open shelves rather than stay chained to the table or hidden in the chest. People used libraries far more often than before and read more frequently than they used to. Library collections expanded and space was added, offering more freedom and room for users to conduct quiet, personal and introspective reading activities. Libraries embraced an influx of users from all walks of life. They could be revolutionaries or pornography writers, enlightened free thinkers or skillful professionals, explorers preparing their next adventure or scientists designing experiments. Users' community was diversified and libraries' collections were multiplied. Confronted with increasingly expanded collections, users were discontented with the simple accession lists or inventory type catalogs, and were not satisfied with the situation of having browsed the shelf to find a book. They wanted libraries to offer them a nice and magical tool which enabled them to find that specific needle in the haystack. In that nice and magical tool, they wanted the appearance of sufficient conceptual and structured information so that they could have an idea what that needle was and what it was about, without stepping into the barn and inspecting the hay in person. Such "wantness" can be 
traced in the balance of decisions how the access points for bibliographic records and catalog systems were determined by librarians. Such "wantness" was precisely captured in Charles Cutter (1837-1903)'s three well-known objectives as to what library catalogs should be. These three objectives are not only his own philosophical remarks on the functions of library catalogs, but also an articulation built on his own practical cataloging experience and observing how users wanted to find books.

\section{The Information Catalog Stage}

Computer and internet technology advanced library catalogs into the information stage. The information highways created by computers and the internet penetrate spatial-temporal, societal and national boundaries and integrate the geographically-dissected globe into a connected village. Human minds and bodies have been remarkably extended and expanded in a way that never happened before in human history. Global citizen, information literate, lifelong learners and civil society are frequently mentioned in pedagogical texts, which cultivate individuals to engage themselves in this ever-changing world with a broader vision, strengthen their information competence and competitiveness, sustain the pursuit of knowledge, and take active responsibilities for democracy and freedom. Educators and policymakers incorporate into educational settings with a consensus that classrooms should help develop three-dimensional (civic, global and digital) citizens, who are "informed, engaged and active," who reflect "global forces, challenges and opportunities," and who reflect "the prevalence of the digital space" (Partnership for 21st Century Skills, 2014, p. 6). Users who attempt to build civic learning and global awareness and grow as digital literacy experts demonstrate a different demographic landscape in library setting. They are more confident and competitive in information utilization and dissemination. They desire more results with less effort, and they want more information autonomy but less subjection. They expect that libraries not only function as book-reading places, but also information commons providing services in an integrative, dynamic and cross-disciplinary model that could contextualize their information needs as a result of synergy between different departments and various professionals (Beagle, 1999, p. 88). They desire an innovative and engaging online catalog adapted to the needs of user communities and operable on handheld devices, particularly smart phones and tablets. They want to transfer the capability of retrieving information gained on commercial websites into an online gateway where the segregated and fragmented catalogs, databases, digital collections and institutional repositories could be synchronized together for one-stop shopping. They want less predetermined scholarly descriptions in online catalogs, which were inherited from the 18th century, and more user-friendly, loosely-controlled, and common-sense-based social tags and applications. They expect that library catalogs not only reflect librarians' perceptions and observations as a technological tool, but also a cultural and social platform that captures the traits of the information age. Fostered by users' expectations, library catalogs as a social space encourage library professionals, either frontline user services librarians or backroom technical services librarians, to rediscover and redefine their roles where traditional boundaries are being blended by emerging situations, and to take risks in an area where responsibilities overlap (Tarulli \& Spiteri, 2012, p. 130). 


\section{CONCLUSION}

This article gives a broad overview of the major milestones in the evolution of library catalogs from ancient times to the 21 st century with a highlight on the discussion of users' rising expectations and needs. Evolution is a term that suggests historical, contemporary and anticipatory gradual growth. It is also a term which delineates the possibility of innovation that grows out of quantitative increase and the potential that the new grows out of the old. In this sense, the development of library catalogs could be considered as an evolving process, which experiences both gradual growth and instant innovation at certain points in its course. These points are the crossing intersections where technology brings revolution to the methods of representing and disseminating information and where we human beings want more and better, guided by our basic inherent desire of doing less. To this point, one would say that we are only at the threshold of the 21 st century, and users' expectations for the gateways that connect themselves with libraries' resources will not pause or remain still. Therefore, it is anticipated that the drastic and profound changes of library catalogs are likely to continue in the near future. Let's be prepared with our ceaseless effort and creativity, experimental boldness and dynamic adaptability.

\section{ACKNOWLEDGEMENT}

I want to thank anonymous reviewers for their valuable suggestion. Special thanks are given to my colleague Professor John Drobnicki for proofreading the manuscript.

\section{References}

Adams, J. A. (1988). The computer catalog: A democratic or authoritarian technology? Library Journal, 113(2), 31-36.

Beagle, D. (1999). Conceptualizing an information commons. The Journal of Academic Librarianship, 25(2), 82-89.

Borgman. C. L. (1996). Why are online catalogs still hard to use? Journal of the American Society for Information Science, 47(7), 493-503.

Casson, L. (2001). Libraries in the ancient world. New Haven: Yale University Press.

Chan, L. M., \& Salaba, A. (2015). Cataloging and classification: An Introduction. Lanham: Rowman \& Littlefield.

Clarke, R. I. (2014). Find, identify, select... socialize? Alternative objectives of library catalogs. Proceedings of the Association for Information Science and Technology, 51(1), 1-5.

De Gennaro, R. (1983). Library automation and networking: Perspectives on three decades. Library Journal, 108(7), 629-635.

Dragomir, V. (2016). The library next generation catalogue revolutionary information access 
instrument. Romanian Journal of Library and Information Sciences, 12(2), 18-26.

Fons, T. (2016). Improving web visibility: Into the hands of readers. Retrieved from http://magz.yabesh.ir/magz/bitstream/handle/emyd/801/Library\%20Technology\%20Reports \%202016\%20(Vol\%2052)\%20(Issue\%2005).pdf

Fromm, G. \& Garton, C. (2013). Marketing to millennials: Reach the largest and most influential generation of consumers ever. New York: AMACOM, American Management Association.

Harris, M. H. (1984). History of libraries in the western world (compact textbook ed.). Metuchen, NJ: Scarecrow Press.

Hildreth, C. R. (1987). Beyond Boolean: Designing the next generation of online catalogs. Retrieved from https://www.ideals.illinois.edu/bitstream/handle/2142/7500/librarytrendsv35i4k_opt.pdf

Johnson, E., D. \& Harris, M. H. (1976). History of libraries in the western world. Metuchen, NJ: Scarecrow Press.

Joudrey, D. N., Taylor, A. G., \& Miller. D. P. (2015). Introduction to cataloging and classification (11 ${ }^{\text {th }}$ ed.). Santa Barbara, Califonia: Libraries Unlimited.

Kaestle, C. F. (1985). The history of literacy and the history of readers. Review of Research in Education, 12, 11-53.

Library of Congress. (2017). The card catalog: Books, cards, and literary treasures. San Francisco: Chronicle Books.

Lyons, M. (2011). Books: A living history. Los Angeles: The J. Paul Getty Museum.

Maxwell, N. K. (2006). Sacred stacks: The higher purpose of libraries and librarianship. Chicago: American Library Association.

Murray, S. A. (2009). The library: An illustrated history. Skyhorse Publishing, Inc.

Nagy, A. (2011). Analyzing the next-generation catalog: A library technology report. Chicago: ALA Editions.

Norris, D., M. (1939). A history of cataloguing and cataloguing methods 1100-1850: With an introductory survey of ancient times. London: Grafton \& Co..

Partnership for $21^{\text {st }}$ Century Skills (2014). Reimaging citizenship for the $21^{\text {st }}$ century: a call to action for policymakers and educators. Retrieved from http://www.p21.org/storage/documents/Reimagining_Citizenship_for_21st_Century_webver sion.pdf

Peters, T. A. (1991). The online catalog: A critical examination of public use. Jefferson, North Carolina: McFarland \& Company.

Ranz, J. (1964). The printed book catalogue in American libraries: 1723-1900. Chicago: American Library Association.

Rose-Wiles, L. M., \& Hofmann., M. A. (2013). Still desperately seeking citation: Undergraduate research in the age of web-scale discovery. Journal of Library Administration, 53(2/3): 147166.

Rosenthal, J. A. (1991). Crumbling walls: The impact of the electronic age on libraries and their clienteles. Journal of library administration, 14(1), 9-17.

Sweeny, R. T. (2006). Millennial behaviors and higher education focus group results: How are 
Millennials different from previous generations at the same age? Retrieved from https://certi.mst.edu/media/administrative/certi/documents/Article-Millennial-Behaviors.pdf

Tarulli, L., \& Spiteri, L. F. (2012). Library catalogues of the future: A social space and collaborative tool? Library Trends, 61(1), 107-131.

Tolzmann, D. H., Hessel, A., \& Peiss, R. (2001). The memory of mankind: The story of libraries since the dawn of history. Delaware: Oak Knoll Press.

Turner, M., \& Cobbe, H. (1990). "Jam tomorrow": The present and future state of the British Library's automated music catalogues. Fontes artis musicae, 37(1), 48-56.

US Census Bureau. (2017). The changing economics and demographics of young adulthood: 1975-2016.

Retrieved

from https://www.census.gov/content/dam/Census/library/publications/2017/demo/p20-579.pdf

Valentine., P. M. (2012). A social history of books and libraries from cuneiform to bytes. Lanham, Maryland: Scarecrow Press.

Wellisch, H. H. (1981). Ebla: The world's oldest library. The Journal of Library History (19741987), 16(3), 488-500.

\footnotetext{
About the author

Professor Diao's current research interests focus on the intersection of library, history and writing through the lens of comparative perspective. His research covers reinvestigation and reevaluation of traditional classification schemes from a cultural perspective, rethinking of cataloging librarians' roles in the age of library digitalization and career deprofessionalization, history of Romanization of Chinese language and related issues in the Library of Congress, and Chinese writing and its impact on Chinese libraries in the course of its history.
} 